\title{
低沸点有機塩素化合物の大気環境中濃度とその挙動
}

\author{
小田 淳子, 前田 泉, 市川 省吾 \\ 岡山県環境保健センター \\ （テ701-02 岡山市内尾739-1）
}

[平成 4 年 4 月 9 日受理 $]$

\section{Atmospheric Concentration and Behavior of Volatile Chlorinated Hydrocarbons}

\author{
Junko ODA, Izumi MAEDA, and Syogo ICHIKAWA \\ Okayama Prefectural Institute for Environmental \\ Science and Public Health \\ (739-1 Uchio, Okayama, 701-02) \\ [Received April, 9, 1992]
}

\begin{abstract}
Summary
Concentrations of volatile chlorinated hydrocarbons ( $\mathrm{VCHs}$ ) in atmosphere were investigated in 1990 to 1991 by GC/MS using a wide-bore capillary column and behavior of these compounds was studied. Atmospheric concentration levels of VCHs in rural district were around one tenth compared with ones in industrial district or indoor. Relationship between atmospheric VCHs concentrations and meteorological parameters or other pollutants concentrations which were measured with automatic instruments were investigated and it was clarified that variation pattern of VCHs concentrations in atmosphere was similar to that of nitrogen oxides (NOx) . Also, this study showed an essential pattern of daily and seasonal variations.
\end{abstract}

Key words: volatile chlorinated hydrocarbons, GC/MS, rural district, daily and seasonal variation, meteorological parameter

\section{1. 緒言}

大気中バックグランド濃度測定調査によるとハロカー ボン類の大気中濃度はわずかずつであるが増加する傾向 を示しており ${ }^{1)}$, ハロカーボン類による成層圈のオゾン 破壊は今や地球規模の問題に発展している。難分解性の 四塩化炭素や1,1,1-トリクロロエタンはクロロフルオロ カーボンと同様, 塩素を成層圈まで運ぶ運搬者として指 摘されており，これら低沸点有機塩素化合物（VCHs） による成層圈のオゾンの破壊が懸念されている ${ }^{1)}$ 。1987 年に提示されたモントリオール議定書では, 特定フロン 5 種と特定ハロン 3 種, その後四塩化炭素及び $1,1,1$-卜 リクロロエタンを含めてその使用及び製造を将来的に制 限または中止する方向が定められた。さらにVCHs は人
体への有害性から化学物質の審査及び製造等の規制に関 する法律で，クロロホルム，1，2-ジクロロエタンは指定 化学物質に, 四塩化炭素, トリクロロエチレン, テトラ クロロエチレンは第 2 種特定化学物質に指定されてい る。このような観点から，これら $\mathrm{VCHs}$ の排出に対する 有効な対策を求めることは極めて重要である。

大気中の $\mathrm{VCHs}$ 濃度は他の污染物質と同様, 気団の移 動や気圧配置等によって, 或いは発生源からの放出量に 依存して大きく変動するので, 大気中における $\mathrm{VCHs} の$ 実態を解明するためには多数のデー夕の収集と長時間サ ンプリングしたデータによる解析が必要と考えられる。 VCHsに関するこれまでの他の調查例 ${ }^{2-9)}$ を見ると, 試 料の捕集は 1,2 時間単位のバッチサンプリング方式が 主体で長時間の連続的捕集が少ないこと, 更に短期間の 
デー夕に基づくものが多く, 特に濃度変動や季節変動を 考慮した長期的な測定は少ない2,3)。また年間を通じた 長期の連続調査の場合では, 試料の自動採取装置を開発 したり ${ }^{4-7)}$, 試料捕集時間を 24 時間或いは 1 週間単位に 長期化して実施しているが8,9)，日変動のように詳細な 変動はつかみにくい。

そこで著者らは大気環境レベルにおける $\mathrm{VCHs}$ の污染 状況を把握するため, 2 時間の連続試料捕集が可能な装 置を作製して採取装置の安定性, 捕集管の破過容量等に ついて検討した。本装置を用いて田園地域の 1 地点に於 いてVCHsを連続的に捕集して11カ月間調査を行った。 調査結果と同期間中の大気污染自動測定機データ及び気 象パラメータデータと比較しその関連性について解析を 行なったところ, 装置の有効性を証明すると共に環境大 気中の $\mathrm{VCHs}$ の日変動, 季節変動について新たな知見を 得たので報告する。

\section{2. 実験装置及び方法}

\section{1 捕集方法}

試料捕集にはガラスライニング製ステンレス管（内 径 1 / 4 インチ, 長さ $18 \mathrm{~cm}$ ) に0.8gの Carbopack B （SUPELCO 社）を充填して捕集管に使用した。この捕 集管は予めキャリヤーガスを流しながら $250^{\circ} \mathrm{C} て ゙ 12$ 時間 程度加熱し, 妨害成分を追い出した後, 室温まで冷却し てステンレス製キャップ（スウェジロック社製）を用い て密栓し, 試料採取まで蓋付きパイレックス製ガラス試 験管内に保存した。捕集管の破過容量及び保持容量の測 定は捕集管を GCに接続して GC カラムとして使用し目 的物質を $\mathrm{GC} に$ 注入した時出現するピークの保持時間と ピーク幅から算出した ${ }^{10)}$ 。また回収率の測定は, 対象 物質の標準ガス試料を予め吸着させた捕集管に清浄空気 $3 \sim 6 \mathrm{~L}$ を通気して捕集管に残存する標準物質量を測定 することにより求めた。試料採取装置は小型ミニポンプ （シバ夕製 MP-2N 型）とフローメー夕を組み合わせて 軽量簡便な装置を作製した。本法での試料捕集は連続 2 時間採取法を採用し，採取流量は $25 \mathrm{ml} / \mathrm{min}$ で行なった。 用いた装置の試料採取精度を検討するため装置 6 台を使 用して実際の環境大気試料 $3 \mathrm{~L}$ を捕集管に同時採取し, 分析を行った。

\section{2 試薬及び標準ガスの錭}

クロロホルム，1,2-ジクロロエタン，1,1,1-トリクロ ロエタン, トリクロロエチレン, テトラクロロエチレン は東京化成工業製（GC用）を, 四塩化炭素は和光純薬 製（特級）を使用した。検量線の作成は VCHs の原液 1 $\sim 2 \mu \mathrm{l}$ を予め洗浄した真空瓶に注入気化させた後, 清 净な窒素ガスで希釈して所定濃度の標準ガスを調製して 行った。

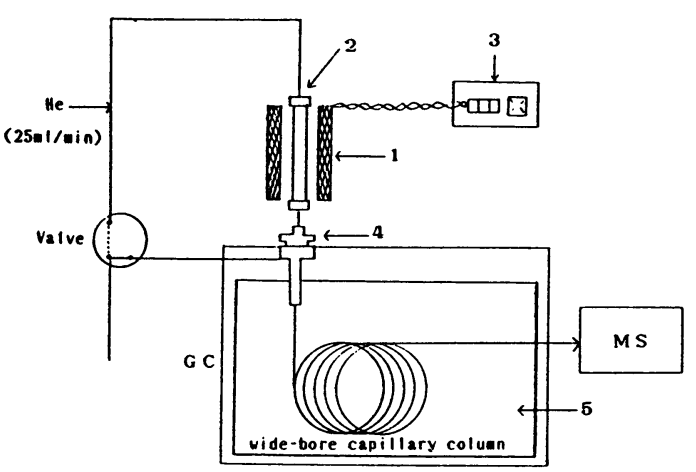

1: Heater block made of aluminum

2: Sampling tube packed with Carbopack B $0.8 \mathrm{~g}$ (made of stainless steel whose inside was coated with glass)

3: Heater controller

4: Sample injection port

5: GC oven equipped with automatic cryogenic system by liquid $\mathrm{CO}_{2}$

Fig. 1 Schematic diagram of the analytical system

\section{3 测定操作}

大気中の $\mathrm{VCHs}$ の測定法には吸着剤に捕集した試料を 加熱してガスクロマトグラフ（GC）に全量導入する方 法 $^{7}$ 11) と吸着片で捕集した成分を溶剤で脱離させ GC （ECD）に導入する方法 ${ }^{12-14)}$ がある。本調查では低濃 度レベルの測定を行うため感度の得られる全量注入法を 採用した。

分析はメガボアカラムを用いた $\mathrm{GC} / \mathrm{MS}$ 法 $^{15)} に よ り$ 行った。分析システムの概要を Fig. 1 に示した。先ず 捕集管（2）の盲蓋をはずして，捕集管の試料採取側に 注射針を取り付け，捕集管を GC 注入部（4）に接続す る。GC カラム恒温槽 ( 5 ) は予め液体炭酸ガスを用いて, $0{ }^{\circ} \mathrm{C}$ に冷却保持した後，キャリヤーガスを捕集管に流し 捕集管を室温から $240^{\circ} \mathrm{C}$ まで約 2 分間で加熱昇温して 10 分間保持し溶出成分をカラムの先端部に再濃縮した。そ の後 GCを分析条件に示したカラム温度プログラムに 従って昇温し，溶出する成分の SIM 測定を行ない，検 量線から各 VCHs の濃度を算出した。SIM 法でモニター するイオンは強度の強いフラグメントイオンあるいは分 子イオン 2 個を各々選んだ。 GC/MSの分析条件は次の ようであった。

Column : DB-1(J\&W) $30 \mathrm{~m} \times 0.53 \mathrm{~mm}$ i.d. 5 um Film thickness

Column temp. $\quad: 0^{\circ} \mathrm{C}(3 \mathrm{~min})-.8^{\circ} \mathrm{C} / \mathrm{min} .-30^{\circ} \mathrm{C}-$ $3{ }^{\circ} \mathrm{C} / \mathrm{min} .-65^{\circ} \mathrm{C}-12^{\circ} \mathrm{C} / \mathrm{min} .-$ $200^{\circ} \mathrm{C}(10 \mathrm{~min}$. 
Carrier gas

: Helium, Head pressure 22Psi

(Flow rate $25 \mathrm{ml} / \mathrm{min}$ )

Injection mode : Packed column inlet

Injection Temp. $\quad: 120^{\circ} \mathrm{C}$ Separater temp.: $200^{\circ} \mathrm{C}$

Ion source temp. $\quad: 230^{\circ} \mathrm{C}$ Ionization voltage: $70 \mathrm{eV}$

Ionization current : $300 \mu \mathrm{A}$

Monitor ion $(\mathrm{m} / \mathrm{z})$ : Chloroform $(83,87)$

1,2-Dichloroethane $(62,98)$

1,1,1-Trichloroethane $(97,119)$

Carbon tetrachloride $(119,121)$

Trichloroethylene $(97,130)$

Tetrachloroethylene $(164,166)$

Instrument

: JEOL JMS-DX303

\section{4 测定地点及び測定時期}

特定の発生源や自動車等の移動発生源が近隣にある場 合は, VCHs の濃度変動はこれら污染物質の影響に大き
く支配されることが考えられる。そこで測定地点は県内 の代表的な田園地域に位置する建物を選定して, 地上か ら $15 \mathrm{~m}$ の高さで行なった。当地点は市中心部及び工業地 域から10数 $\mathrm{km}$ 離れた地点に位置し，周囲の影響を受け にくい状況下にある。また気象測定用自動測定機を備え ている。測定期間は, 季節の気象状況と大気の安定性を 考虑して 5 期間を選定した。Fig. 2 は山頂（岡山市高倉 山）と地上（岡山市南輝）の気温の差の 1 時間値を月平 均值で示したものである。気温差が小さいときは大気が 安定になる傾向があり，大気は 7 月頃に不安定，12月頃 に安定になりやすい。これを基に春型気象として 4 月下 旬を, 梅雨明け後の夏型気圧配置として 7 月下旬を，秋 の気象として10月下旬を，大気が安定な傾向を示す時期 として12月中旬を，冬型の気圧配置として 2 月中旬を選 定した。測定期間中は各時期とも3〜4 日間の連続採取 とした。採取時期とその気象状況は表 1 の通りであった。
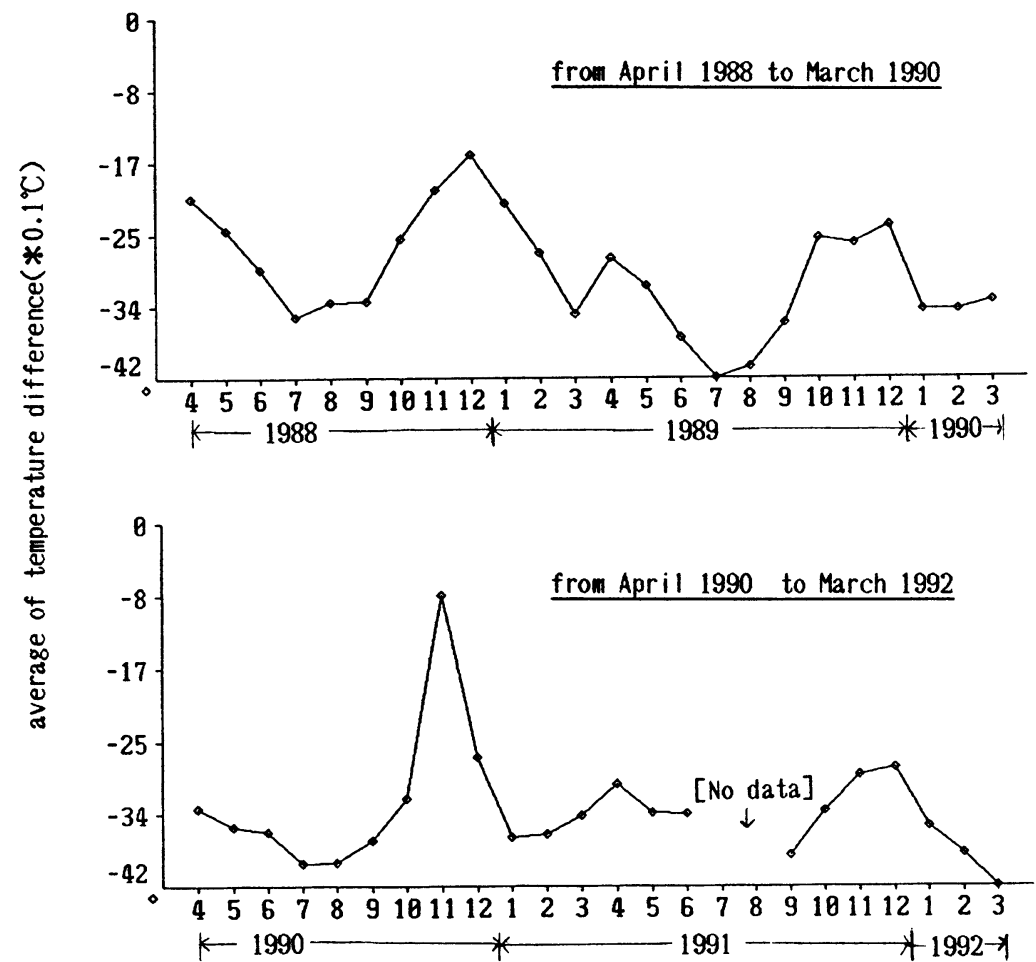

Fig. 2 Monthly variation of temperature difference at Okayama City from April 1988 to March 1992

Temperature difference means a value on subtraction of temperature at the ground $5 \mathrm{~m}$ below the sea from temperature at the mountaintop $450 \mathrm{~m}$. Monthly average of temperature difference was calculated by using the following equation.

Monthly average of temperature difference $=\frac{\text { temperature difference } * \text { appearance frequency of the hour }}{\text { meseared time number in a month }}$ 
Table 1 Meteorological conditions during sampling periods（試料採取時期の気象の概要）

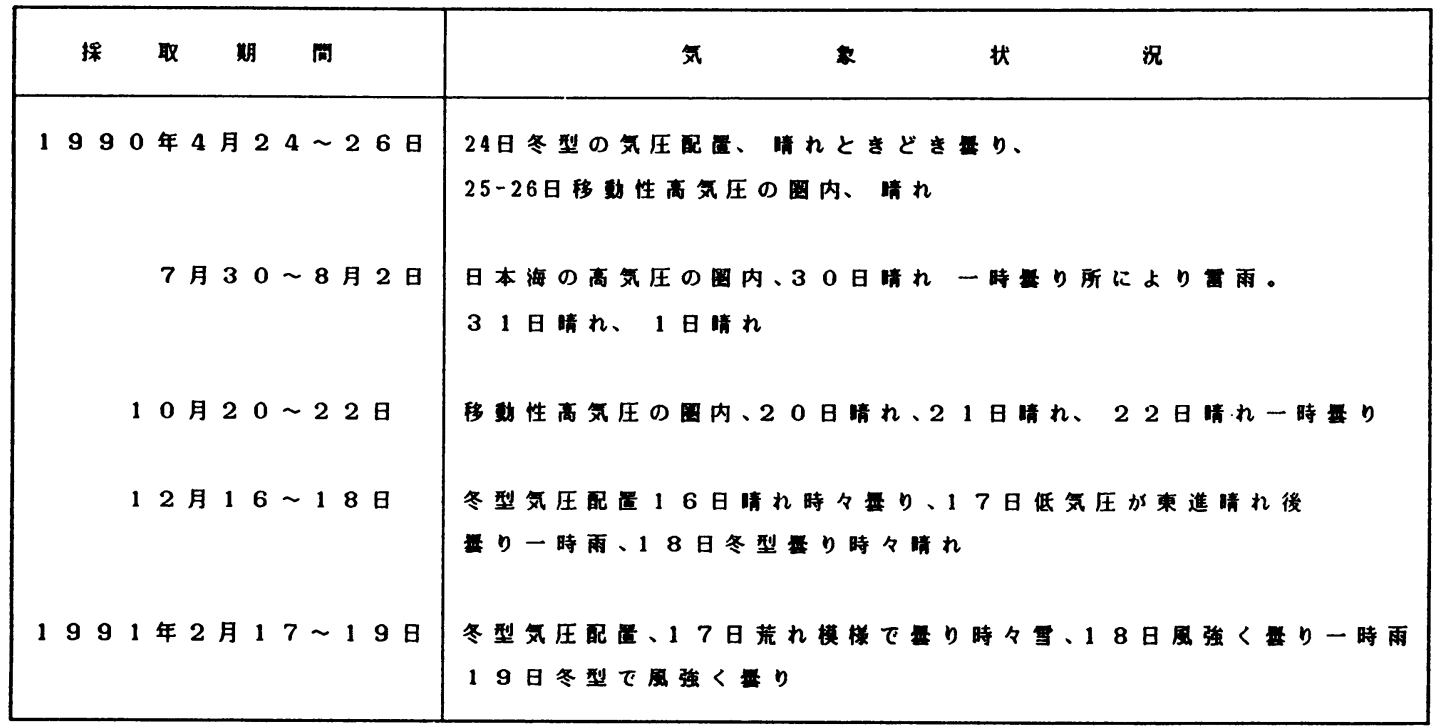

\section{5 自到测定墥による酎定}

$\mathrm{VCHs}$ の挙動の解析に自動測定機データのうち風速 (WV) 及び温度 (TEMP) は試料採取地点の自動測定 機データを使用した。また, 二酸化硫黄 $\left(\mathrm{SO}_{2}\right)$, 二酸化 室素 $\left(\mathrm{NO}_{2}\right)$, 一酸化窒素 $(\mathrm{NO})$, 浮遊粒子状物質 $(\mathrm{SPM})$, オキシダント $(\mathrm{OX})$, メタン $\left(\mathrm{CH}_{4}\right)$, 非メタン $\left(\mathrm{nCH}_{4}\right)$, 湿度 (RHUM)，日射量 (SUN) は試料採取地点から約 $500 \mathrm{~m}$ 近傍に位置する大気污染監視測定局のデー夕を使 用した。

\section{3. 結果と考察}

\section{1 捕集方法の模时}

\section{1.1 捕集管及び装置の性能}

Table 2 はVCHs の保持容量及び破過容量を示したも のである。対象とする 6 物質の $30^{\circ}$ Cにおける保持容量は $3.4 \mathrm{~L}$ 以上であった。破過容量は，クロロホルムが $2.9 \mathrm{~L}$ でやや $3 \mathrm{~L}$ を回ったが他は $3 \mathrm{~L}$ 以上であった。空気 3 Lを通気した回収率試験では，本捕集管で VCHs が保持 できることが明らかになった。

\section{1. 2 採取装贯の安定性}

Table 3 は低流量 $(25 \mathrm{ml} / \mathrm{min})$ で綝り返し試料採取 を行なった時の装置の安定性について調べた結果であ る。変動率はクロロホルム,テトラクロロエチレンが各々 19\%と $36 \%$ でやや大きい値を示したが, 他は 6 〜 11\%で あった。クロロホルムとテトラクロロエチレンは検出下 限値付近の低浱度レベルで検出されたためと思われる。

\section{2 環境大気中の濑定姞果}

3. 2. 1 環境大気中の湍度レベル

Table 4 は検出した低沸点化合物 6 物質の平均値, 検 出範囲（最小值一最大值）及び変動率を示したものであ る。物質別にみると $1,1,1$-トリクロロエタンが 0.26 $8.63 \mu \mathrm{g} / \mathrm{m}^{3}$, 平均值 $2.44 \mu \mathrm{g} / \mathrm{m}^{3}$ を検出し, 最も濃度が 高かった。平均値の最も低いのは1,2-ジクロロエタンの $0.22 \mu \mathrm{g} / \mathrm{m}^{3}$ であった。変動率の最も低かったのはテト ラクロロエチレンの $46 \%$ であるが, 変動率の最も高かっ たのはトリクロロエチレンの187\%である。

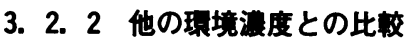

今回得られた VCHsのデータが他の VCHs 環境浱度と 比較してどの滣度レベルにあるかを見るため, 工業地域 周辺測定結果及び同時期に行った室内の測定結果との比 較を行った。Table 5 にその結果を示す。一般住宅の室 内 (台所, 居間) ではクロロホルムが $8.06 \mu \mathrm{g} / \mathrm{m}^{3} て ゙$ 田 園環境平均浱度の16倍, 1,1,1-トリクロロエタンが4.61 $\mu \mathrm{g} / \mathrm{m}^{3}$ で約 2 倍の高浱度を示した。一方, 研究施設に おいてこれらの VCHs を使用していない実験室の測定例 では, クロロホルムが $19.45 \mu \mathrm{g} / \mathrm{m}^{3}$ で田園環境平均浱度 の40倍, 1,1,1-トリクロロエタンが $8.12 \mu \mathrm{g} / \mathrm{m}^{3}$ で約 3.2 倍であり, 四塩化炭素が $7.25 \mu \mathrm{g} / \mathrm{m}^{3}$ で5.7倍, テト ラクロロエチレンが $11.96 \mu \mathrm{g} / \mathrm{m}^{3}$ で35倍の高港度を示し た。一般住宅においてこれらの VCHs を高浱度に検出し た理由としては, 室内に使用されている建築資材等から の分解発生が考えられる。一方, 研究施設の実験室内で VCHs を使用していないにも関わらず高瀑度で検出され 
Table 2 Retention volume and breakthrough volume of VCHs

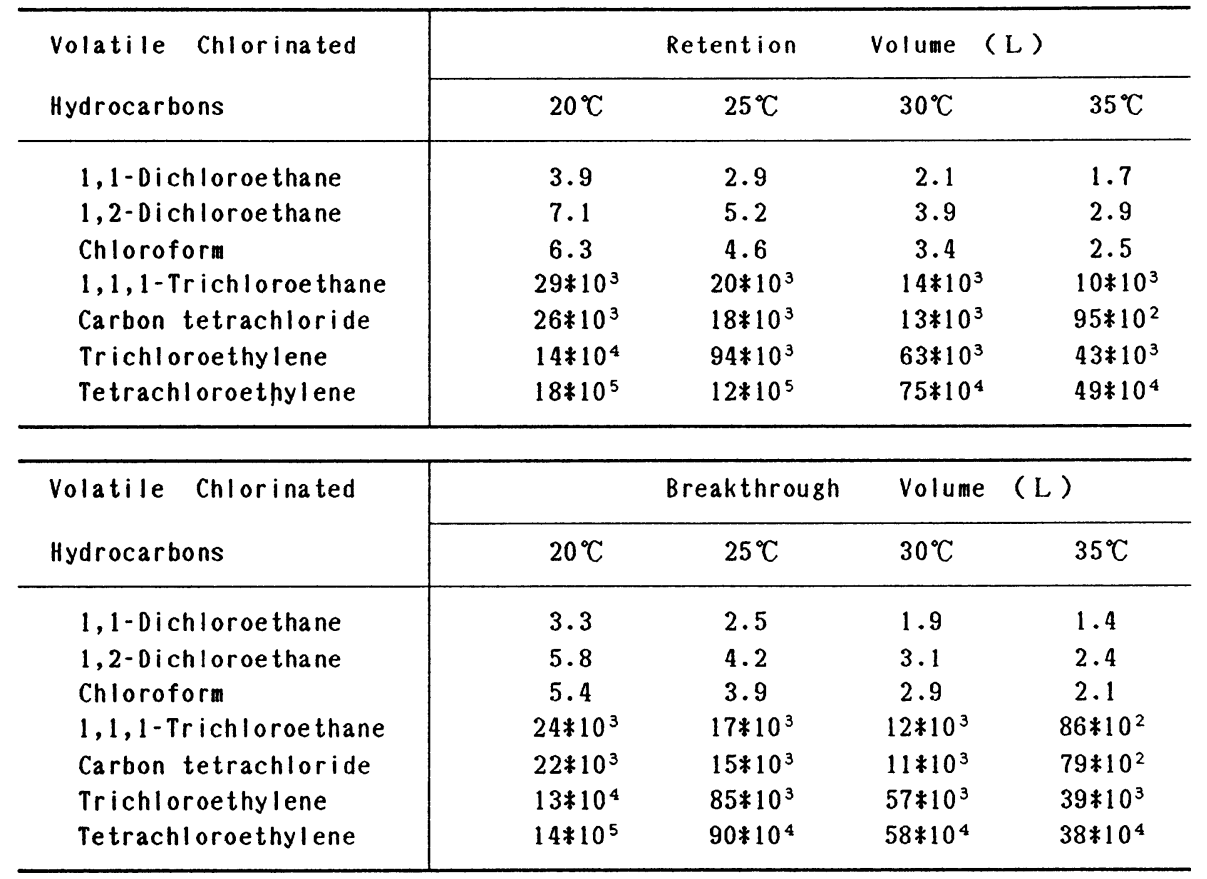

Table 3 Precision of sampling system

\begin{tabular}{l|ccc}
\hline \multicolumn{1}{c|}{ Compound } & Mean $\left(\mu \mathrm{g} / \mathrm{m}^{3}\right)$ & S.D. & C.V. (\%) \\
\hline Chloroform & 0.16 & 0.03 & 19 \\
1,2-Dichloroethane & 0.30 & 0.03 & 8.8 \\
$1,1,1$-Trichloroethane & 1.37 & 0.09 & 6.9 \\
Carbon tetrachloride & 2.41 & 0.15 & 6.4 \\
Trichloroethylene & 0.40 & 0.04 & 11 \\
Tetrachloroethylene & 0.10 & 0.02 & 36 \\
\hline \multicolumn{1}{c}{ Notes : } & n $=6$ & S.D. $;$ Standard deviation \\
& C.V. $;$ Coefficient of variation
\end{tabular}

Table 4 Atmospheric concentrations of VCHs in rural district

(April, July, August, October, December/1990, February/1991)

\begin{tabular}{l|ccccc}
\hline \multicolumn{1}{c|}{ Compound } & Sample number & Mean & Range(Min.-Max.) & C.V.(\%) & Detection limit \\
\hline Chloroform & 137 & 0.47 & $0.04-3.61$ & 110 & 0.04 \\
1,2-Dichloroethane & 138 & 0.22 & $0.05-1.15$ & 89 & 0.03 \\
$1,1,1-T r i c h l o r o e t h a n e$ & 137 & 2.44 & $0.26-8.63$ & 61 & 0.04 \\
Carbon tetrachloride & 137 & 1.24 & $0.36-3.49$ & 53 & 0.10 \\
Trichloroethylene & 135 & 0.53 & $0.03-7.03$ & 187 & 0.03 \\
Tetrachloroethylene & 138 & 0.33 & $0.061-0.93$ & 46 & 0.01 \\
\hline
\end{tabular}


たが、これは他の室で VCHs を用いている可能性がある ことに加えて冬期の暖房使用で施設内空気が循環してい るため污染を受けたことによると思われる。また工業地 域周辺の戸外環境では, 夏期に於ける濃度が田園地域の 年間平均濃度より全体として 10 倍高い濃度で検出され た。冬期の濃度は $0.08 \sim 0.87 \mu \mathrm{g} / \mathrm{m}^{3}$ であり田園地域の $0.49 \sim 2.57 \mu \mathrm{g} / \mathrm{m}^{3}$ と比較的近い低濃度レベルであった。 工業地域周辺環境の夏期濃度が田園地域より高い理由と して, 当地区には1,2-ジクロロエタン, トリクロロエチ レン, 四塩化炭素等 VCHs の取扱い事業所が存在してい るためと考えられる。

しかし, 田園地域の VCHs 濃度は高い濃度順に1,1,1-
トリクロロエタン>四塩化炭素＞トリクロロエチレン> クロロホルム>テトラクロロエチレン>1,2-ジクロロエ タンであり，工業地域（夏期）周辺環境では1,2-ジクロ ロエタン>四塩化炭素>トリクロロエチレン>テトラク ロロエチレン>クロロホルム $>1,1,1$-トリクロロエ夕ン の順であることから, 田園地域の VCHs は工業地域の影 響をを受けていないことが明らかになった。

また,これらの測定結果を川本, 浦野氏らの報告によ る日本での環境中 VCHs 濃度の測定例 ${ }^{16)}$ と比較すると, 田園地域での測定データは大気中濃度レベルの範囲内に あるが, 都市大気に比べて低濃度側に位置することが判 明した。

Table 5 Comparison of concentration levels of VCHs in air (1989-1991)

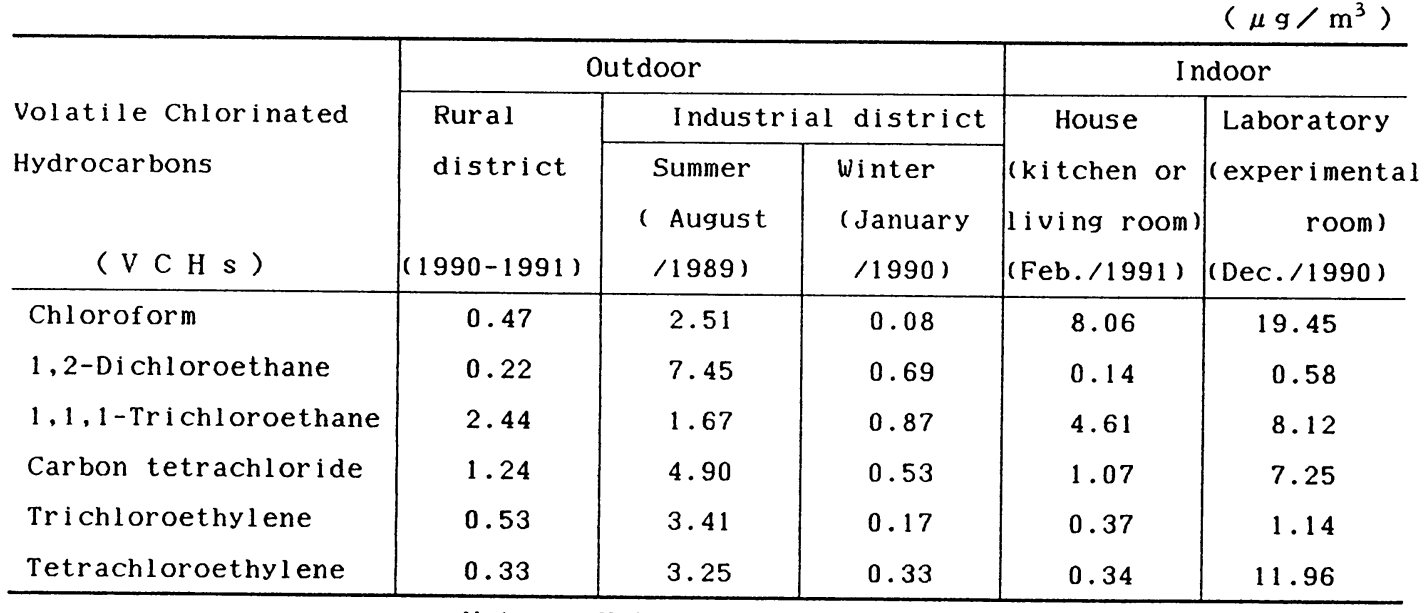

Notes : Values are the average of $4 \sim 138$ measurements

Table 6 Correlation coefficients between atmospheric VCHs concentrations and meteorological parameters or other pollutants

\begin{tabular}{|c|c|c|c|c|c|c|c|c|c|c|c|}
\hline \multirow{2}{*}{$\begin{array}{l}\text { Volatile Chlorinated } \\
\text { Hydrocarbons(VCHs) }\end{array}$} & \multicolumn{11}{|c|}{ Meteorological parameters and pollutants by automatic measuring instrument } \\
\hline & N02 & NO & $\mathrm{SO2}$ & SPM & $0 \mathrm{X}$ & CH4 & $\mathrm{n}-\mathrm{CH} 4$ & WV & TEMP & RHUM & SUN \\
\hline Chloroform & +0.14 & +0.06 & +0.28 & $*+0.32$ & -0.01 & +0.10 & -0.01 & -0.07 & +0.19 & +0.08 & +0.04 \\
\hline 1,2-Dichloroethane & $\neq+0.28$ & +0.12 & $\neq+0.39$ & $\neq+0.45$ & +0.11 & -0.02 & -0.07 & +0.03 & +0.06 & -0.05 & +0.05 \\
\hline 1,1,1-Trichloroethane & $*+0.40$ & $*+0.45$ & -0.06 & +0.16 & $*-0.46$ & $*+0.39$ & $*+0.38$ & -0.22 & -0.15 & $*+0.41$ & $*-0.27$ \\
\hline Carbon tetrachloride & +0.05 & -0.01 & -0.20 & -0.07 & +0.01 & -0.09 & 7 & +0.24 & -0.28 & +0.13 & -0.04 \\
\hline Trichloroethylene & $*+0.36$ & $*+0.31$ & -0.18 & +0.02 & -0.23 & +0.07 & to. & +0.12 & $*-0.46$ & $*+0.27$ & -0.12 \\
\hline Tetrachloroethylene & *+0.52 & $*+0.46$ & $*+0.32$ & $*+0.45$ & -0.19 & +0.15 & +0.20 & -0.14 & -0.07 & +0.11 & +0.02 \\
\hline total V.C.H. & $*+0.41$ & $*+0.38$ & +0.02 & +0.27 & $*-0.29$ & +0.21 & +0.21 & -0.05 & -0.17 & $\neq+0.32$ & -0.14 \\
\hline
\end{tabular}

Notes: $N 02=n i t r o g e n$ dioxide, $N 0=$ nitrogen monoxide, $S 02=s u l$ fur dioxide, SPM=suspended particle material, $0 X=0 x i d a n t, C H 4=$ methane, $n-C H 4=$ non methane, $W V=w i n d$ speed, TEMP=temperature on ground, RHUM=relative humidity, SUN=solar irradiation $\quad *=p<0.001$ Measurements were taken in 1990-1991 ( $n=138)$ 


\section{2.3 污染物質と自動測定機データとの関連}

前項で述べたように田園地域の VCHs デー夕は局地的 污染の影響を受けていないデー夕であることが明らかに なった。VCHs が他の污染物質とどのような関連性を持 つかを調べるため自動測定機データと比較検討した。自 動測定機データは 1 時間値を基本にしているため, 同期 間中の 2 時間平均值を求めて解析に供した。Table 6 に $\mathrm{VCH}$ と自動測定機データ11項目との相関係数, 有意性 検定の結果を示している。自動測定機による他の污染質 との関連性をみると, クロロホルム, 四塩化炭素を除く 4 種の VCHs は $\mathrm{NO}_{2}$ と危険率 $0.1 \%$ で有意であり，また 1,2-ジクロロエタン, テトラクロロエチレンは $\mathrm{SO}_{2}$, SPM と弱いながら正の相関が認められた。気象項目と の関連ではトリクロロエチレン及び1,1,1-トリクロロエ タンが温度または湿度と相関が認められた。

\section{2. $4 \mathrm{VCHs}$ 濃度の変動要因}

VCHs 濃度の変動要因を解明するため 138 個のデータ について主成分分析を行った結果をTable 7 に示す。 主成分分析の 20 因子のうち固有值 1 以上を示した第 4 成 分までを抽出した。各々の固有値と共通性の中に占める 割合は第一因子（Z1）が5.19（26\%)，第 2 因子（Z2） が3.92（20\%)，第 3 因子（Z3）が2.64（13\%），第 4 因子（Z4）が1.65（8\%）で全因子の $67 \%$ であった。 各固有ベクトル值を比較すると, 第 1 因子で1,1,1-トリ クロロエタン，テトラクロロエチレン，総 VCHs 量 (totalVCHs) が各々 $-0.31,-0.25,-0.27$ で $\mathrm{NO}_{2}, \mathrm{NO}$ の-0.36, -0.30 と同じ負方向にベクトル值を持ち, OX の0.32とは逆向きベクトル值を示している。Fig. 3 及び 4 に1,1,1-トリクロロエタン, テトラクロロエチレン, $\mathrm{NO} 2, \mathrm{NO}$ の時系列変化を示したが, 類似した変動が認

Table 7 Results of principal ingredient analysis among VCHs, meteorological data and other pollutants

\begin{tabular}{|l|rrrr|}
\hline VCHs, other pollutant & \multicolumn{4}{|c|}{$(\mathrm{F}=138 \mathrm{c}$ t o r } \\
\cline { 2 - 5 } meteorological parameter & $\mathrm{Z} 1$ & $\mathrm{Z} 2$ & $\mathrm{Z3}$ & $\mathrm{Z} 4$ \\
\hline Chloroform & -0.05 & 0.26 & 0.17 & -0.34 \\
1,2-Dichloroethane & -0.02 & 0.34 & 0.19 & 0.02 \\
1,1,1-Trichloroethane & -0.31 & 0.01 & 0.19 & -0.09 \\
Carbon tetrachloride & -0.20 & 0.01 & 0.38 & -0.27 \\
Trichloroethylene & -0.22 & -0.03 & 0.33 & 0.02 \\
Tetrachloroethylene & -0.25 & 0.20 & 0.20 & 0.19 \\
total-VCHs & -0.27 & 0.07 & 0.34 & -0.15 \\
S O 2 & 0.02 & 0.45 & -0.15 & 0.07 \\
S P M & -0.17 & 0.37 & -0.18 & 0.12 \\
O X & 0.32 & 0.26 & 0.20 & 0.06 \\
N O 2 & -0.36 & 0.06 & -0.14 & 0.12 \\
N O & -0.30 & -0.04 & -0.12 & 0.21 \\
C H 4 & -0.11 & 0.05 & -0.35 & -0.37 \\
n- C H 4 & -0.28 & -0.05 & -0.14 & 0.33 \\
W V & 0.19 & -0.19 & 0.35 & -0.04 \\
T E M P & 0.15 & 0.36 & -0.20 & -0.20 \\
R H U M & -0.28 & -0.14 & -0.20 & -0.35 \\
S U N & 0.22 & 0.23 & 0.13 & 0.28 \\
\hline
\end{tabular}

\begin{tabular}{|l|rrrr|}
\hline \multicolumn{1}{|c|}{-} & $\mathrm{z} 1$ & $\mathrm{z} 2$ & $\mathrm{z3}$ & $\mathrm{z4}$ \\
\hline peculiar value & $5.19^{\cdots}$ & 3.92 & 2.64 & 1.65 \\
contribution rate & 0.26 & 0.20 & 0.13 & 0.08 \\
cumulative contribution & 0.26 & 0.46 & 0.59 & 0.67 \\
\hline
\end{tabular}

Notes : SO2=sulfur dioxide, SPM=suspended particle materials, NO2=nitrogen dioxide, NO=nitrogen monoxide. $\mathrm{OX}=$ oxidant, $\mathrm{CH} 4=$ methane, $n-\mathrm{CH} 4=$ non methane, $W V=w$ ind speed, $T E M P=$ temperature on ground RHUM=relative humidity, SUN=solar irradiation 


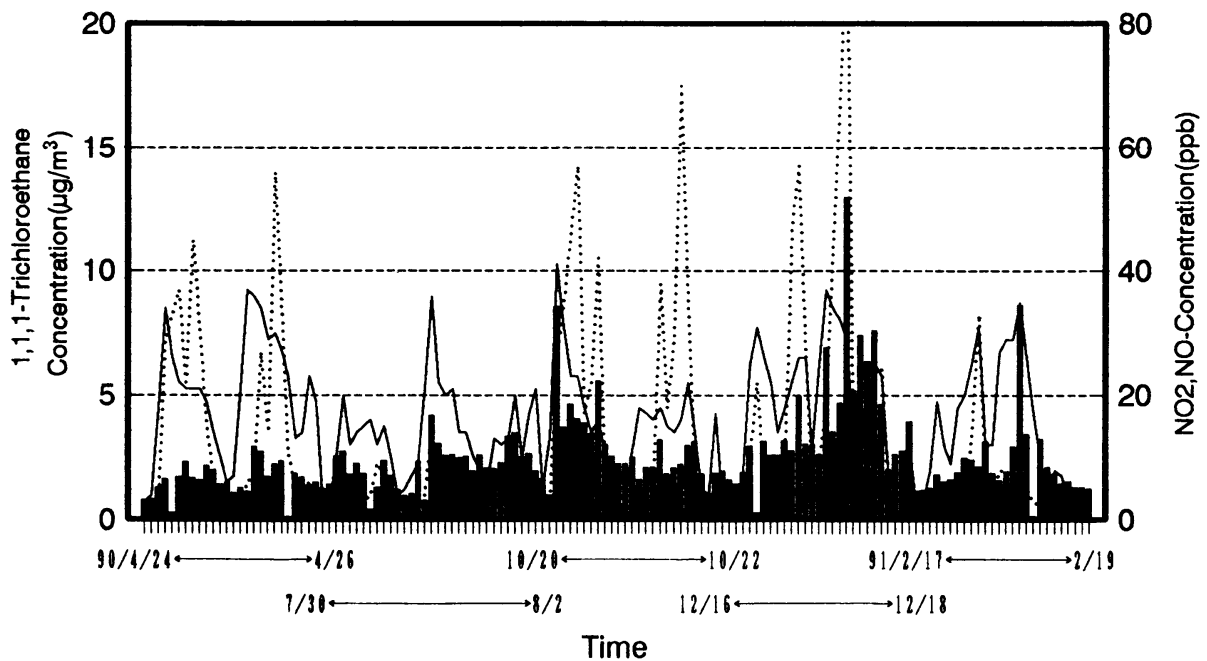

Fig. 3 Timely variation of atmospheric concenatrations in 1990-1991

[1,1,1-Trichloroethane; Nitrogen dioxide; Nitrogen monoxide] 1,1,1-Trichloroethane Nitrogen dioxide Nitrogen monoxide

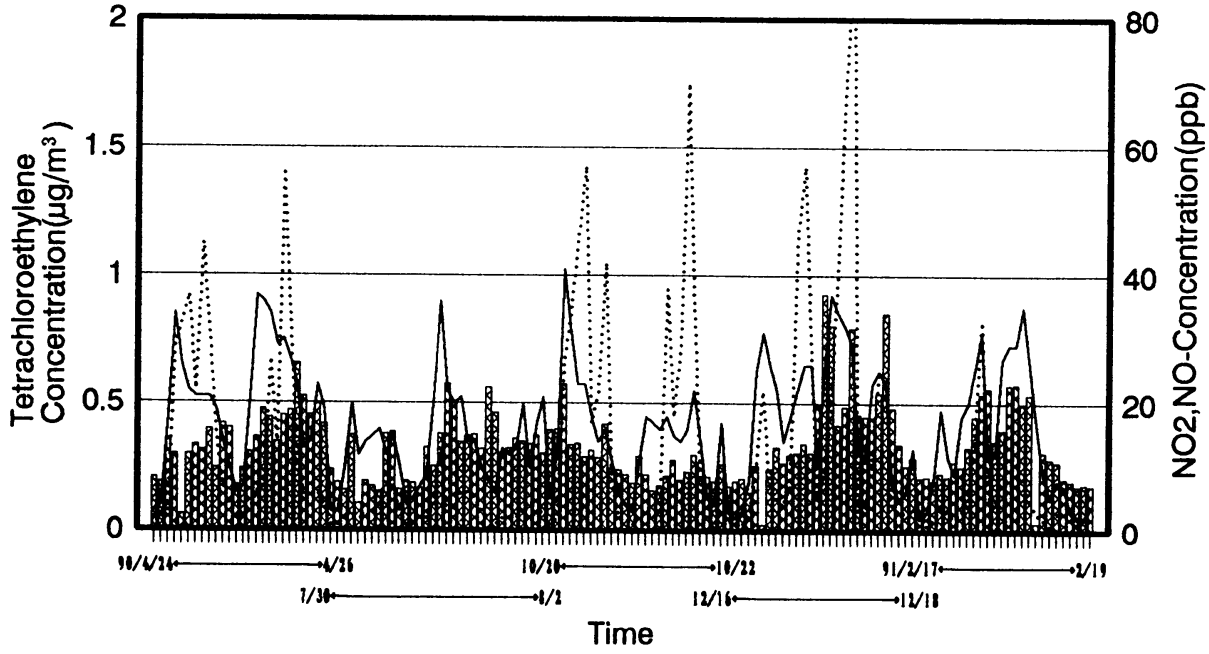

Fig. 4 Timely variation of atmospheric concentrations in 1990-1991

[Tetrachloroethyene; Nitrogen dioxide; Nitrogen monoxide]

Tetrachloroethylene Nitrogen dioxide Nitrogen monoxide

められた。第 2 因子では1,2-ジクロロエタン, $\mathrm{SO}_{2}, \mathrm{SPM}$, 温度は正值であり同方向のベクトル值を示した。第 3 因 子では四塩化炭素, トリクロロエチレンの0.38,0.33に 対して風速が $0.35 て ゙$ 正方向に, メタン, 非メタンが-0.35, -0.14 で負方向の值を示した。第 4 因子はクロロホルム, 四塩化炭素がメタン, 湿度と同じ負方向に, 非メタンと 逆向きのベクトルを示した。第 1 ，第 2 及び第 3 因子の 性格を明らかにするため各主成分スコアと，関連する項
目の自動測定機のデータをプロットすると,Fig. 5 に示 すように第 1 因子と $\mathrm{NO}_{2}$ では相反した変動パターンが 認められた。OX, 気温, 日射量は日中に高く, 夜間に 低くなるのに対し，逆に $\mathrm{NO}_{2}$ 濃度は日中に低く，夜間に 高くなるという日変動を示し，第一因子は日変動に関係 の深い因子と考えられる。Fig. 6 は第 2 因子と温度との 関係を示しているが, 類似した変動パターンを持ち, 夏 期に高く冬期に低くなることから第 2 因子は季節変動に 


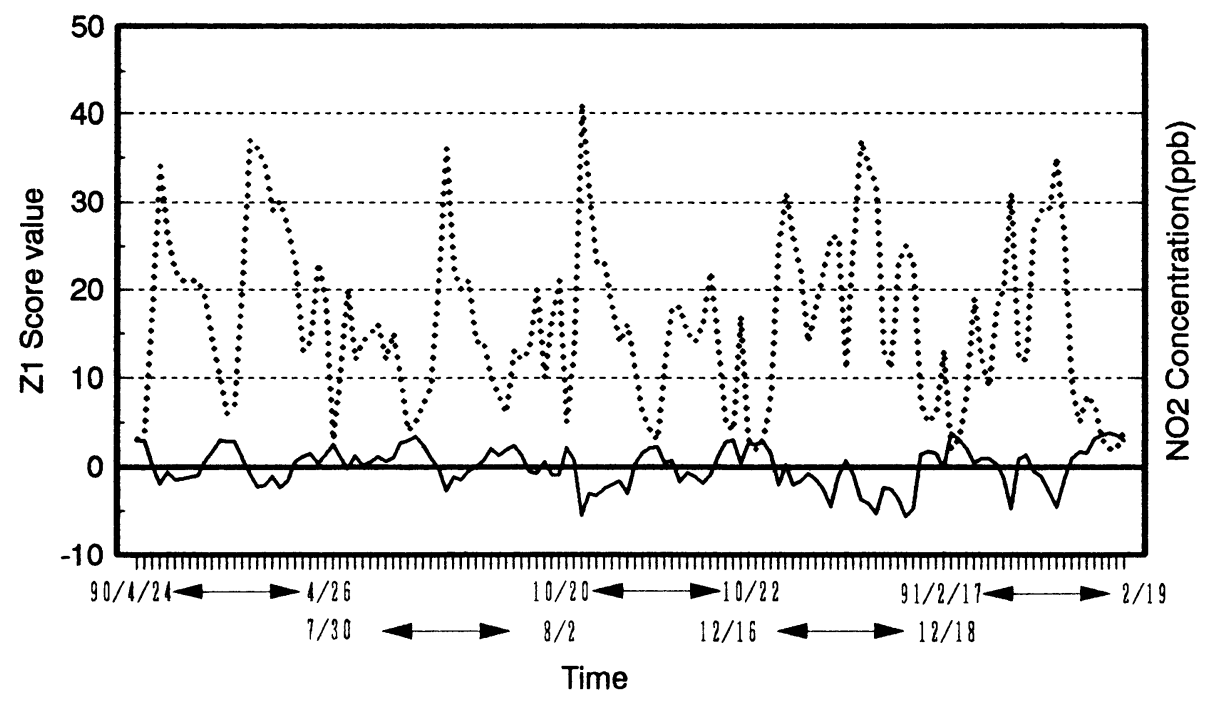

Fig. 5 Variation pattern of $\mathrm{Z1}$-score and $\mathrm{NO}_{2}$ concentration Score Z1 NO2

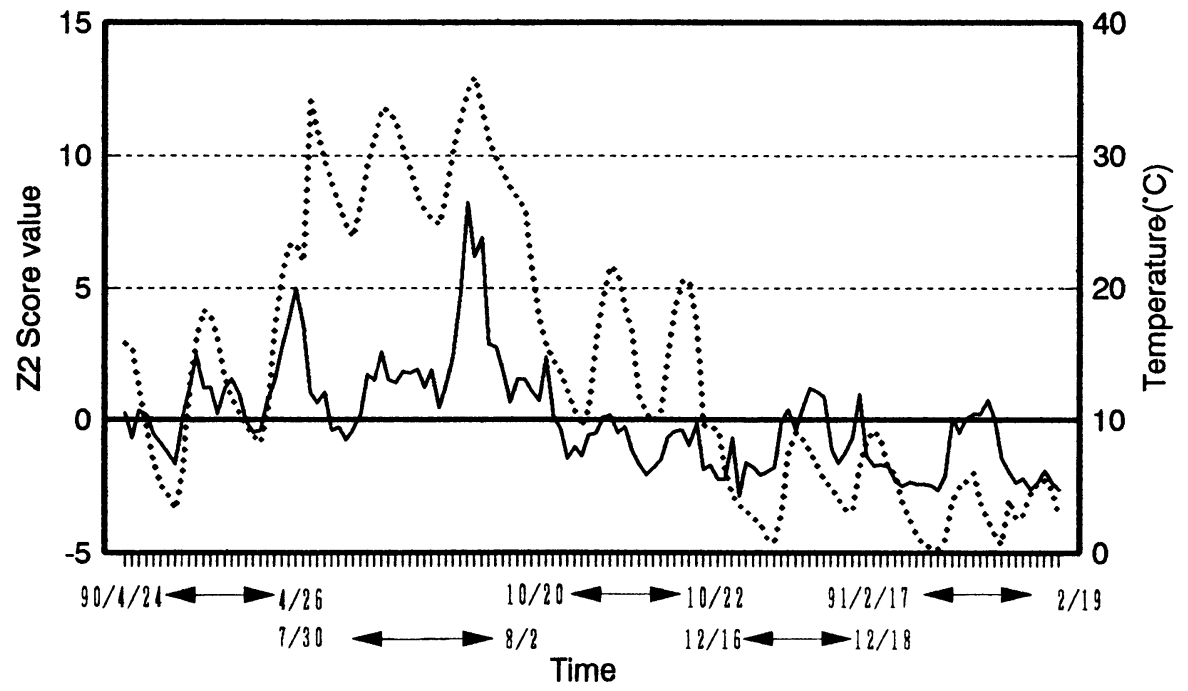

Fig. 6 Variation pattern of Z2-score and temperature

Score Z2 Temperature

関係のある因子と考えられる。Fig. 7 は第 3 因子の各ス コアと風速データの関係を示し, 類似のパターンが認め られた。第 3 因子は污染物質のトリクロロエチレン, 四 塩化炭素が正方向に, メタン, 非メタンが負方向を示す 動きからみて污染物質の風による移入と考えられる。第 4 因子については関連項目をプロットしてみたが明確な 意味付けは困難であった。

\section{2. $5 \mathrm{VCHs}$ の変动}

自動測定機デー夕との解析によって, VCHsには日変
動があることが推定された。全測定デー夕について 2 時 間の単位による各時間帯毎に該当するデータの平均値を 求めてFig. 8 に示した。物質により濃度差はあるが, いずれも日の出後数時間経過した $8 \sim 10$ 時と，日没後数 時間経過した20〜22時頃の戍にピークを示すことが認め られた。より詳細に検討するため1,1,1-トリクロロエ夕 ン，トリクロロエチレン及びテトラクロロエチレンの 4 月の日変動を 2 時間毎にFig. 9 に示した。測定期間中 の気象概況は高気圧に覆われて榣やかに晴れ, 放射冷却 


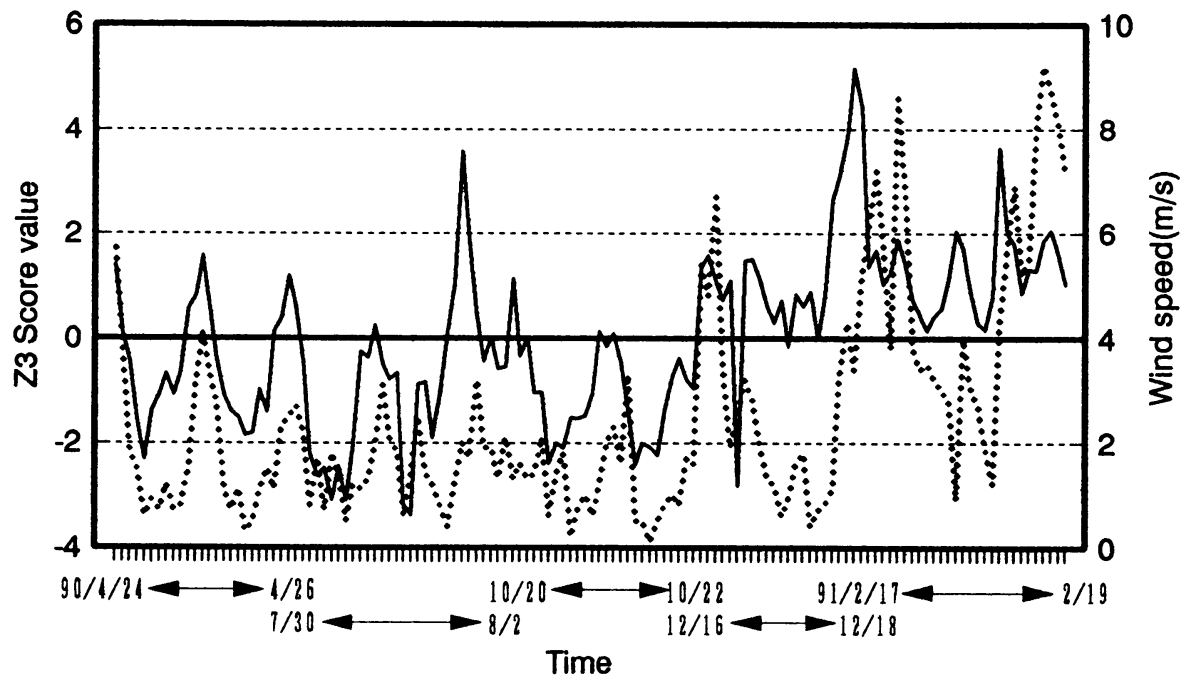

Fig. 7 Variation pattern of Z3-score and Wind speed Score Z3 Wind speed

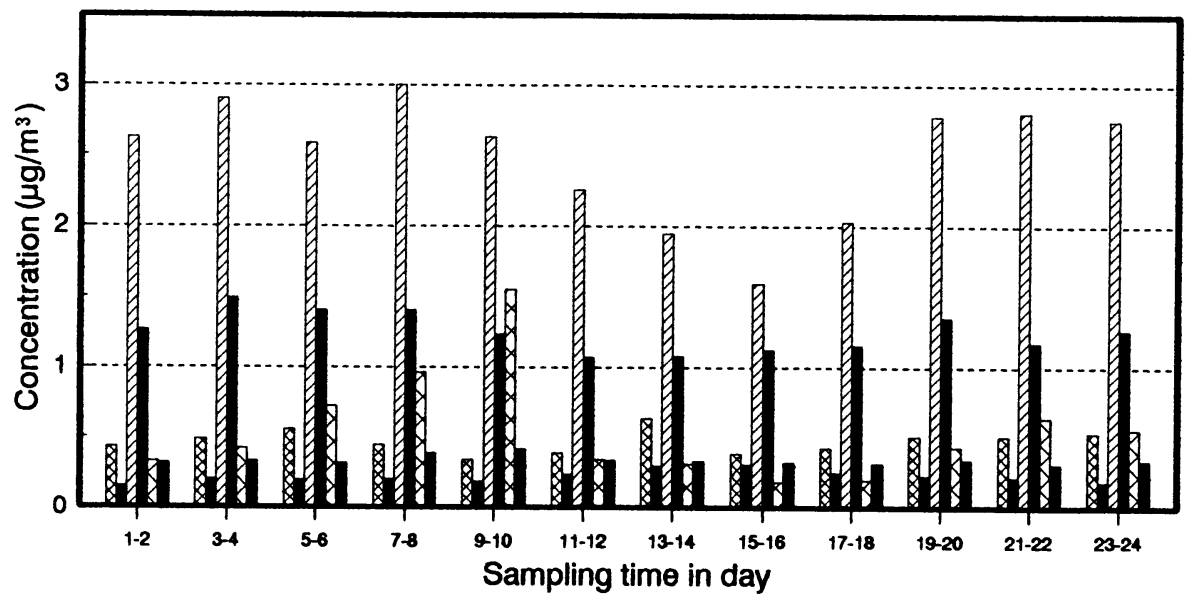

Fig. 8 Daily variation of average concentrations of VCHs on sampling time
Chlorotorm
1,2-Dichloroethan
1,1,1-Trichloroethane
Carbon tetrachloride
Q] Tilchloroettrylene
Tetrachloroettrylene

が進んで冷え込みが強かった。第 1 日目は冬型の気圧配 置で, 日中風速 $7 \mathrm{~m}$ の強い北〜西 $(\mathrm{NW})$ 系の風が吹い て一般風が主であったが，2 日目から風は弱まり南〜東 系（SE）に変わり，一般風から海陸風が入った。第 3 日目から風速は更に弱まり，南～西（SW）系の海陸風 が発達して同時に日中の温度も徐々に上昇した。Fig. 9 で 3 物質はいずれも凪に上昇し, 海陸風が発達してくる につれて濃度の減少が認められた。

\section{2. $6 \mathrm{VCHs}$ の季䈨変動}

Fig.10は季節別の VCHs 濃度を示している。12月に $\mathrm{VCHs}$ 各物質の平均值濃度が高く，4 月，10月には濃度 が低くなる季節変動を示した。このことは他の自動測定 機デー夕の季節変動と比較すると，夏期低く，12月高く なるという同様の変動パターンが認められた。

気温, 風速等の気象要因が日変動及び季節変動をする と同様に $\mathrm{NO}_{2}, \mathrm{NO}, \mathrm{SPM}$ 等の污染質も日変動及び季節 変動をするといわれている ${ }^{17)}$ 。Giorgio らはイタリアの 

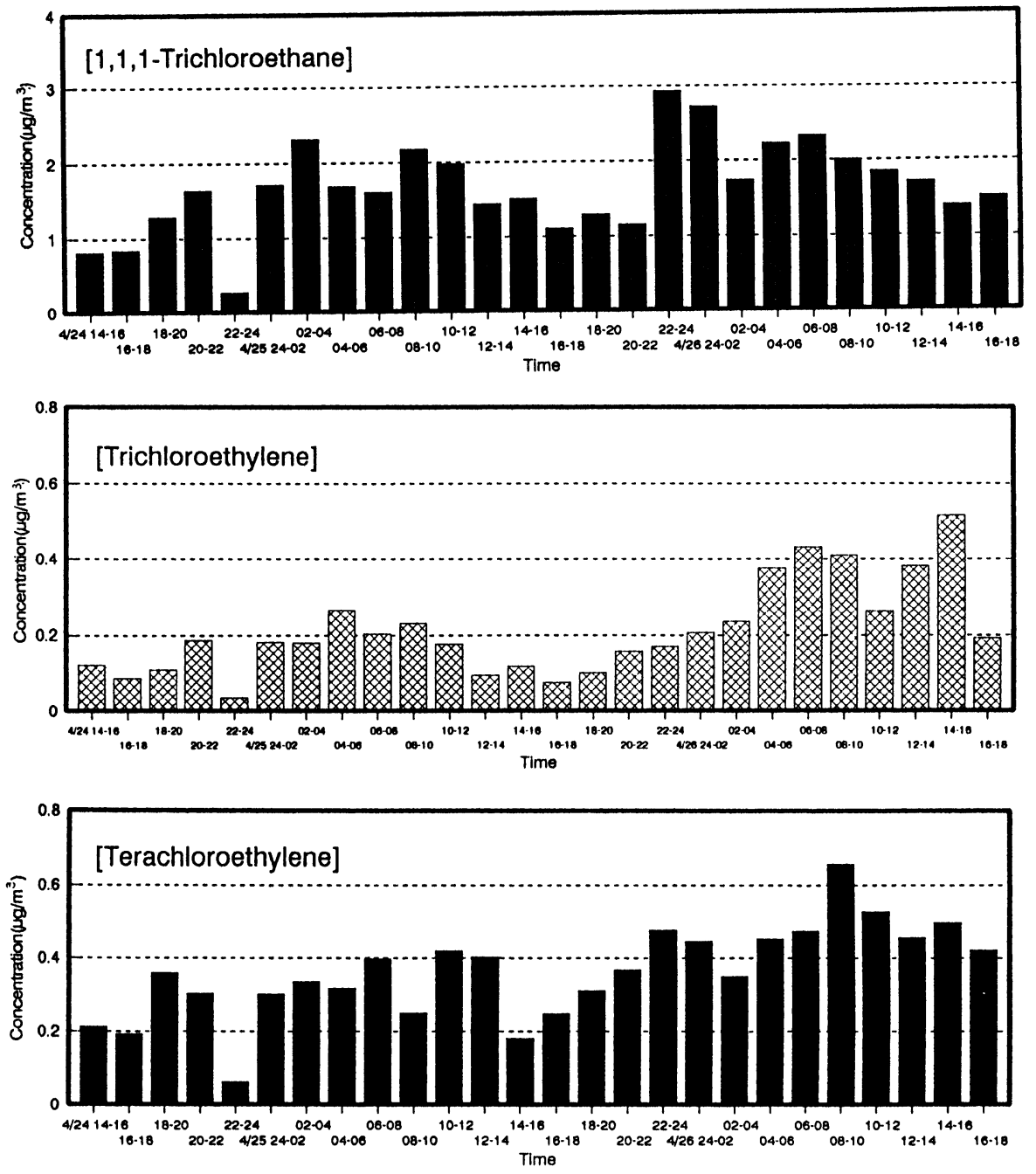

Fig. 9 Daily variation of atmospheric concentrations of $\mathrm{VCHs}$ in 24-26 April

都市大気及び人血液中 VCHs の定量により, 日変動, 季 節変動が存在することを報告している ${ }^{18)}$ 。本結果は大 気中 VCHs 濃度の挙動について一部を解析したものであ るが, Giorgioらと類似した知見が認められた。

\section{4. まとめ}

VCHs は人体に対する安全性や環境污染への䋰念か ら, 大気中への排出対策を求めることは極めて重要であ る。大気中の VCHs の挙動を解明するため, 試料捕集法 の検討と連続試料採取による調査を行い, VCHs 濃度と 自動測定機データとの関連性について解析した。

（1）大気中のVCHs 濃度の測定に, Carbopack B を用 いた大気試料の常温吸着捕集と予め液体炭酸ガスで冷却
した GCワイドボアカラムへの試料の再濃縮法を組み合 わせた測定方法を採用した。その結果, 特にキャピラリー カラムへのガス試料導入装置を使用せず低濃度レベルで の分析が可能であることがわかった。

（2）田園地域における大気中 VCHs の測定では，その 濃度は日本での報告例のレベル範囲にあるが, 低濃度域 にあった。また，一般住宅及び研究施設の室内や夏期の 工業地域周辺環境における VCHs 濃度とは約 $1 / 10$ 低い濃 度であった。

( 3 ) VCHs の大気中に於ける挙動は他の污染物質と同 様日変動及び季節変動をすることが明らかになった。 


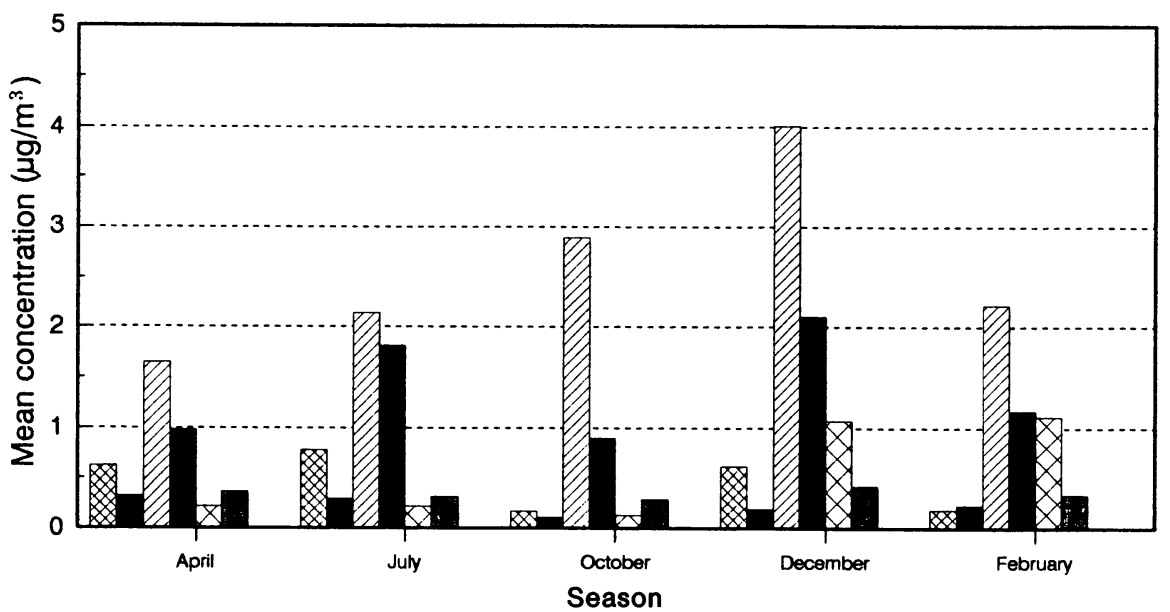

Fig. 10 Seasonal variation of atmospheric concentrations of VCHs

Chlorotorm 1,2-Dichloroethane $\square$ 1,1,1-Trichloroethane

Carbon tetrachloride E Trichloroethylene a Tetrachloroethylene

\section{謝 辞}

本研究を行うに当たり, 大気の安定性について貴重な 資料と御助言をいただいた岡山市公害監視センターの藤 原福一氏に深謝致します。

\section{要 約}

大気中における低沸点有機塩素化合物の挙動を解明す る目的で，ワイドボアカラムを用いた GC/MSで，1990 〜1991年にかけてこれらの濃度実態調査を実施した。田 園地域における低沸点有機塩素化合物の大気中濃度レベ

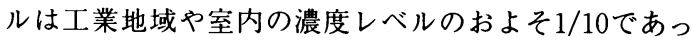
た。大気中の低沸点有機塩素化合物濃度と自動測定機に よる気象パラメータ及び他の污染物質との関連について 検討した。大気中の低沸点有機塩素化合物の変動パター ンは窒素酸化物の動きに似ていること，また明らかに日 変動, 季節変動をすることが認められた。

\section{文 献}

1）富永健：大気中のハロカーボンのバックグランド濃 度, 環境技術, 10,344-348（1981）

2) 堂道和彦, 片岡真樹夫, 山本 修, 小谷茂夫他 : 環 境大気中未規制物質調査, 広島市衛生研究所年報, 4, 73-77（1984）

3）飯田芳男, 代島茂樹：環境大気中の揮発性有機塩素 化合物の濃度, 第31回大気污染学会講演要旨集, 332 (1990)

4）横内陽子, 前田恒昭：揮発性有機物質の吸着濃縮／
キャピラリーガスクロマトグラフィーによる全自動 分析，ぶんせき，1，100-104（1990）

$5 ）$ 横内陽子, 安部喜也：大気中1,1,1-トリクロロエ夕 ン, トリクロロエチレン, テトラクロロエチレンの 低温濃縮／キャピラリーガスクロマトグラフィー／ 水素フレームイオン化検出法による連続自動測定, 分析化学, 38, 40-45 (1989)

6) 浅井勝一, 後藤正志, 渡辺 伸, 石井大道: オンカ ラム低温濃縮／キャピラリーガスクロマトグラ フィーによる作業環境中の有機溶剤混合蒸気の同時 定量, 分析化学, 38, 218-223 (1989)

7 ）沖 典男, 山崎富夫, 吉岡昌徳, 奥野年秀 : オート サンプラーを用いた大気中のハロゲン化炭化水素の 測定, 兵庫県立公害研究所研究報告, 21, 53-57(1989)

8）長谷川敦子, 前田裕行ほか, 神奈川県臨海地区大気 污染調査協議会：神奈川県臨海地区におけるフロン 及び有機塩素系物質の環境濃度調査, 第32回大気污 染学会講演要旨集, 222 (1991)

9）川本克也, 浦野絋平 : 大気中有機ハロゲン化合物長 期モニタリングのための捕集方法, 日本化学会誌,

9, 1746-1752 (1987)

10) Seshadri, S., Bozzelli, J. W.: Collection of vapors of selected chlorocarbons and benzene on tenax GC. Chemosphere, 12, 809-820 (1983)

11）環境庁環境保健部保健調査室：「平成 2 年度化学物 質分析法開発調査報告書」, 250-255（1991）

12) Kebbekus, B. B., Bozzelli, J. w.: Determinaion of selected toxic organic vapors in air by adsorbent 
trapping and capillary gas chlomatography, J. Environ. Sci. Health Part A Environ. Sci. Eng., 17, 713-723 (1982)

13）環境庁環境保健部保健調査室：「平成 2 年度化学物 質分析法開発調査報告書」, 238-249（1991）

14）浦野絋平, 川本克也, 安部欣文, 大作正寿：低沸点 有機塩素化合物の大気中濃度と摄取量評価, 公害と 対策, 24, No. 13，1369-1378（1988）

15）小田淳子, 前田 泉, 市川省吾: 低沸点有機塩素化 合物の環境大気中濃度と挙動について, 第31回大気 污染学会講演要旨集, $263(1990)$
16）川本克也, 浦野絋平：大気中有機ハロゲン化合物の 測定方法と調查例, 大気污染学会誌, 21, 179-190, (1986)

17）森口 実, 千秋鋭夫, 小川 弘：環境濃度の解析手 法, pp. 111-120, 「環境污染と気象」, 朝倉書店, 東京 (1990)

18) Giorgio, G., Roberto, B., Enzo, S.: Volatile halogenated hydrocarbons in urban atmosphere and in human blood. Arch. Environ. Health, 45, 101-106 (1990) 